\title{
Community Dermatology: Necessity or Hype?
}

${ }^{\star}$ Rushma Shrestha ${ }^{1}$, Niraj Parajuli ${ }^{2}$, Anupama Karki ${ }^{1}$

\section{Authors Info:}

${ }^{1}$ Associate Professor, Department of Dermatology and Venereology, National Academy of Medical Sciences, Bir Hospital ${ }^{2}$ Assistant Professor, Department of Dermatology and Venereology, National Academy of Medical Sciences, Bir Hospital

\section{*Corresponding Author:}

Dr. Rushma Shrestha

E-mail :rushma_100@yahoo.com

\section{Disclaimer:}

Conflict of Interest: None

Source of Support: None

Copyright (c) 2019 by author(s), licensed under the Creative Commons Attribution International License 4.0.

\section{ABSTRACT:}

Skin diseases are common all over the world with high prevalence in developing countries with significant socioeconomic and behavioral impact. In Nepal it is the fourth leading cause of nonfatal diseases. A community clinic is the term used for a specialist clinic provided in a Primary Care setting. The aim of these clinics in Nepal is to improve access to basic health services including family planning, child health and safe motherhood. But there are no policies for dermatological diseases in the rural communities. As skin diseases do not usually cause mortality, it is often ignored. But the morbidity is often high and the impact on quality of life is also high. Conducting regular skin camps at inaccessible parts of the country is a good way to provide service to the people of the community and due to the fact that most skin conditions can be diagnosed visually, the method of tele-dermatology can be successful.

Keywords: Community dermatology, Skin diseases, Nepal, Health camps, Tele-dermatology

\section{Article Info}

Received: October 19, 2019

Accepted: November 26, 2019

Published Online: December 22, 2019

How to cite this article in Vancouver Style?

Shrestha R, Prajuli N, Karki A. Community Dermatology: Necessity or Hype?. Europasian J Med Sci 2019; 1(1):69-71. https://doi.org/10.46405/ejms.v1i1.14

\section{Access this article online}

\section{Publisher Note:}

The Europasian Journal of Medical Sciences (EJMS) is an official Journal of Nirvana Psychosocial Care Center \& Ressearch Institute www.nirvanapscc.com. The Journal as well as publisher remain neutral with regards to any jurisdictional claims in any published articles, its contents and the institutional affiliations of the authors.

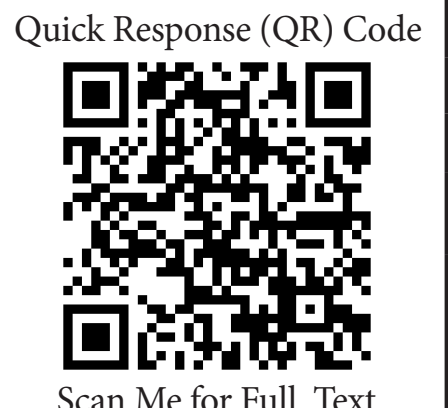


INTRODUCTION

Gin diseases are common all over the world with Shigh prevalence in developing countries with significant socioeconomic and behavioral impact. ${ }^{1}$ In European countries, it was reported to be the fourth leading cause of nonfatal diseases ${ }^{2}$, which is similar to that of Nepal. ${ }^{3}$

A community clinic is the term used for a specialist clinic provided, usually by a Consultant, in a Primary Care setting. Services provide specialist care and advice to patients referred by General Practitioners (GP's) on a number of non-chronic skin conditions that do not require long-term hospital follow-up or a multidisciplinary or sub-specialist services. ${ }^{4}$

There are primary health care outreach facilities in Nepal as well, which was extended to the village level under the National health Policy in 1991 but was limited due to accessibility factors and were therefore initiated in 1994. The aim of these clinics is to improve access to basic health services including family planning, child health and safe motherhood. ${ }^{5}$ There are no policies for dermatological diseases in the rural communities of Nepal.

\section{DISCUSSION}

I n 2012, Shrestha DP et al conducted a large scale, population based study in 18 wards of 10 villages, in the 3 eco-zones ( 2 in Dolakha in the mountainous region, 3 each in Makawanpur and Kavre in the hills and 2 in Chitwan in the terai region) of the central development region of Nepal and found that the prevalence of skin diseases was $25 \% .{ }^{6}$ This study was purely based on dermatology health camps for which the villagers with skin diseases were pre-identified by local health personnel and then examined by the dermatologists during the health camps. Many other published data on skin diseases in rural areas are based on multi-specialty health camps, where the prevalence of skin diseases are much less as compared to the prevalence of proper dermatological health camps. ${ }^{7,1}$

In the year 2017/2018, the total number of patients attending dermatology out patient department of Bir Hospital, which is a tertiary referral hospital of Nepal, was 46,250 . The number of patients is at an increasing rate as compared to the previous year, which were
43,403. ${ }^{8}$ Most of the patients attending here are from very remote areas and of low socio-economic status. So, frequent travelling to Kathmandu is not always feasible for them. Even if they come for check-up, they are not able come for follow-ups. So they continue using the same medicine for a long period of time, which leads to its side-effects. As skin diseases do not usually cause mortality, it is often ignored. But the morbidity is often high and the impact on quality of life is also high. ${ }^{6}$

There are around 21 teaching hospitals in Nepal and only few with provision of specialty training programs. The specialty residency-training programs in Nepal are mostly of 3 years duration and during this time, atleast 3 months of community posting is proposed mandatory for the resident doctors. The experience with the community posting has been wonderful both for the resident doctors as well as the residents of the community. We have had great response from the villagers when the residents were posted there. But is it sufficient? It is obvious that the general population would benefit a lot if a dermatologist was available at the district hospital all year round. But due to lack of adequate trained manpower, it does not seem feasible.

The government has made health strategies for the coming year, some of which are establishment of zonal and regional hospitals to provide specialized services related to paediatrics, gynaecology, general surgery, general medicine, eye care, dermatology, orthopaedics and psychiatry with extending specialist curative care services to remote areas, as and when required, through mobile teams. ${ }^{9}$

\section{WAY FORWARD}

In our view, conducting regular skin camps at inaccessible parts of the country is a good way to provide service to the people, as we have seen that the community benefit a lot from these camps. Also, new concepts like tele-dermatology $y^{10,11}$ and mobile teledermatology ${ }^{12}$ are emerging. This method might be of great use in country like ours with so diverse and difficult to access landscapes. Due to the fact that most skin conditions can be diagnosed visually, the method of tele-dermatology can be successful. 


\section{REFERENCES}

1. Kumar A, Shrestha PR, Pun J, Thapa P, Manandhar M, Sathian B. Burden of dermatological diseases in a remote hilly region of western Nepal: A community health camp-based study. American journal of public health research 2015; 3:203-205. Google Scholar | Full $\underline{\text { Text }}$

2. Svensson A, Ofenloch RF, Bruze M, Naldi L, Cazzaniga $\mathrm{S}$, Elsner $\mathrm{P}$ et al. Prevalence of skin disease in a population-based sample of adults from five European countries. British journal of dermatology 2018; 178: 1111-1118. https://doi.org/10.1111/bjd.16248 Google Scholar $\mid \underline{\text { CrossRef }}$

3. Shrestha DP, Baral S, Shrestha R, Gupta S, Bhattarai $\mathrm{S}$, Shrestha $\mathrm{S}$ et al. Frequency and pattern of Skin Disorders in Adolescents in a School of Kathmandu. Journal of Institute of Medicine 2015, 37(1):21-25. $\underline{\text { Google Scholar } \mid \underline{\text { Full Text }}}$

4. BAD Outreach Clinic Guidance for Dermatology Services 2013. Full Text

5. Annual health Report 2015/2016, Department of Health Services. Ministry of Health, Kathmandu, Nepal. Full $\underline{\text { Text }}$

6. Shrestha DP, Gurung D, Shrestha R, Rosdahl I. Skin diseases and impact on quality of life in the central development region of Nepal. Journal of Institute of Medicine 2014; 36(2):15-20. Google Scholar $\mid$ Full Text
7. Shrestha R, Kayastha BMM. Pattern of skin diseases in a rural area of Nepal. Nepal Journal of Dermatology, Venereology and Leprology 2012; 12(2):41-44. https://doi.org/10.3126/njdvl.v10i1.6422 Google Scholar | CrossRef

8. Kayastha BMM. Annual report of the department of dermatology and venereology 2074B.S (2017/18A.D). Souvenir book of Bir Hospital 2018; 17-20. Full Text

9. Annual health report 2016/2017. Department of Health Services. Ministry of Health, Kathmandu, Nepal. Full Text

10. Neupane S. Teledermatology in Nepal: Where are we? Nepal Journal of Dermatology, Venereology and Leprology 2009; 8(1):3840. https://doi.org/10.3126/njdvl.v8i1.5718 Google Scholar $\mid \underline{\text { CrossRef }}$

11. Jha AK, Gurung D. Reaching the unreached: A model for sustainable community development through information and communication technology. J Nepal Med Assoc 2011;51(184):21314. https://doi.org/10.31729/jnma.36

\section{Google Scholar | CrossRef}

12. Shrestha DP, Baral S, Gurung D, Uprety A, Bhattarai S, Rosdahl I. Mobile teledermatology for rural Nepal: Dermatologic care using mobile phone in a primary health care centre. Journal of Institute of Medicine 2016; 38(1):7-10. Google Scholar | Full Text 